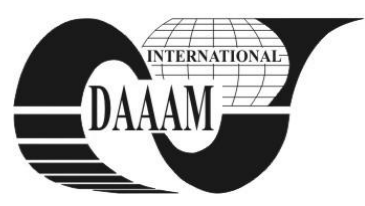

Annals of DAAAM for 2012 \& Proceedings of the 23rd International DAAAM Symposium, Volume 23, No.1, ISSN 2304-1382 ISBN 978-3-901509-91-9, CDROM version, Ed. B. Katalinic, Published by DAAAM International, Vienna, Austria, EU, 2012 Make Harmony between Technology and Nature, and Your Mind will Fly Free as a Bird

\title{
RESEARCH ON THE WORK ENVIRONMENT DATA ACQUISITION IN AUTOMATIC MODE AND USE OF THE ERP SYSTEMS
}

\author{
POPESCU, C[onstantin] - A[drian]; ENCIU, G[eorge]; \\ NICOLESCU, A[drian] F[lorin] \& AVRAM, G[eorgia] - C[ezara]
}

\begin{abstract}
The effective functioning of an automated system is dependent on its ability to gather information from the operating environment and to use enterprise resource planning in a more appropriateway. Information acquisition is done through sensors and hardware interfaces then transferred and stored on servers in the data stream of ERP systems through software interfaces. This paper aims to highlight how data is acquisitionedfrom the work environmentand its processing in order to beinserted in the flow of ERP systems.

Keywords: ERP, sensors, data acquisition, information flow
\end{abstract}

\section{INTRODUCTION}

An Enterprise Resource Planning (ERP) is a complex software package (Fig. 1), used in managing a variety of processes that occur in a company. In the production process [2] planningtakes account ofsaleorders and sale orders raw resources for optimal use of existing production lines. Also in this category enter features such as demand or supply equipment for interfacing with various data acquisition and real time monitoring of production parameters. Combining these features, ERP helps to shorten time to market a product, compliance orders production, increase quality and reduce costs, strategic objectives for any producer.

\section{EXPERIMENTAL EQUIPMENT}

Data acquisition for introduction in ERP systems (Fig. 2) was achieved in a manufacturing cell [3] whose structure consists of a Castingssupply system- FMS 350 with three stations of storage and a drill GP $45 \mathrm{NC}$.

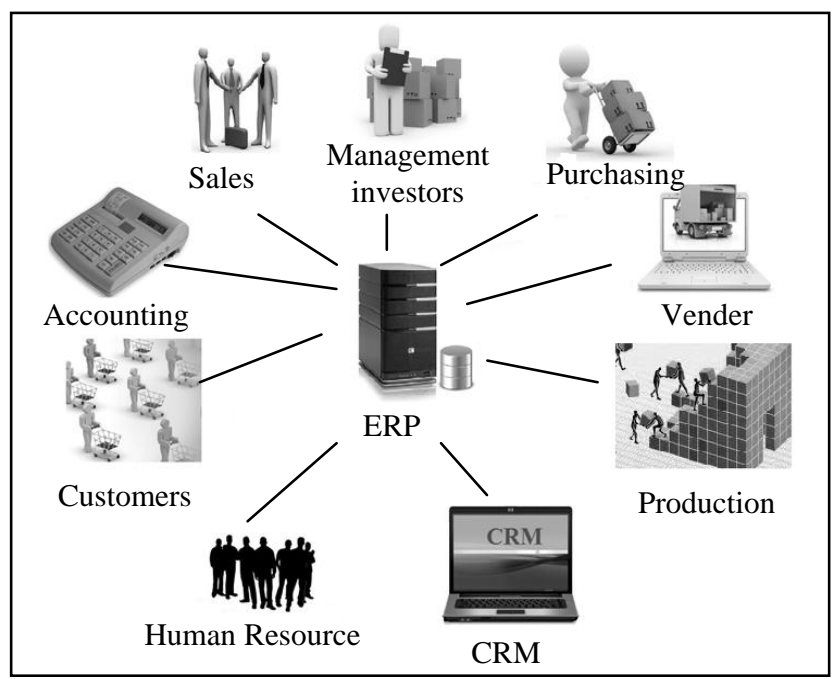

Fig. 1. Module ERP

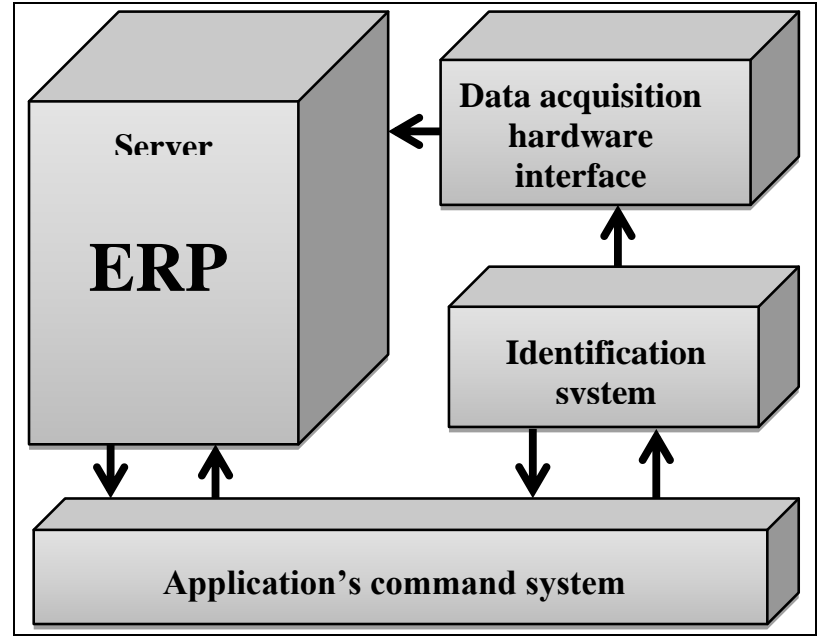

Fig. 2. General block scheme corresponding to the application's information system

\subsection{Presentation ofthe general structureof the} cellmanufacturing

The mainelements of theflexiblecell(Fig. 3)arestorageposts(1)supply system, transportation, transfer(2) drillfitted withapaddlelockon the table(3).

The food, transportation, transfer [1] FMS 350 is based on the drilling machine CNC CN 45 GP.

It achieved, using 3 kinematic chains, the blades transfer with semi-finished parts from the storage positions to the machine table tools and after completion of this operation, the machined parts are transferredfrom the machine table to the storage stations.

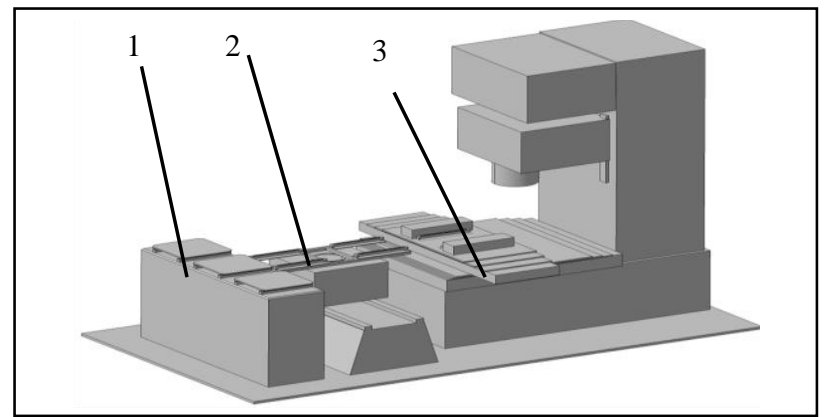

Fig. 3. Flexible manufacturing cell - virtual model

2.2.Description of power system functioning, transport, transfer FMS 350

Phases of work for the mass transfer pallets with semi machine tools are described below:

a. Positioning of the transfer station right storage.

b. Extension arms transfer system to take over the blade with semi. 
c. Blocking the transfer system palette followed by withdrawal of arms to Castings.

d. Rotating the transfer system and its positioning in the right workstation.

e. Extension arms with a view to transfer its semifabricating piece on machine table tools.

f. Blocking tool palette on the machine table.

g. Release of the transfer system palette.

h. Withdrawing arms transfer system.

\subsection{General structure of power, transport, transfer}

\section{FMS 350}

Housing type parts are processed, the blades are positioned on the machine table by means of a locking system (Fig. 4).

Stocking stations, three in number, are embedded in a common support, position adjustment can be done individually. Each workstation is equipped with a second set of limiting the role of referral of this range (Fig. 5).

Blades, with sides of $350 \mathrm{~mm}$, clamping surface have practiced M8 holes and holes for the transfer system and the inner surface of the guidance system and bilateral holes for connection to the system block (Fig. 6).

Robocar (Fig. 7) is made welded and can move in longitudinal direction on a stand with it.The grip on foundation support rails and storage stations is classic, allowing horizontal and vertical adjustment.

Actuatorscorresponding to thethreekinematic chainsareAC. Shelfguidesarerollingelements. Bevelgear(Fig. 8)allowfor rotationdirectionchanginghorizontalscrew-nut mechanismsthatmoveon bothsides of theshelf-piece portblades.

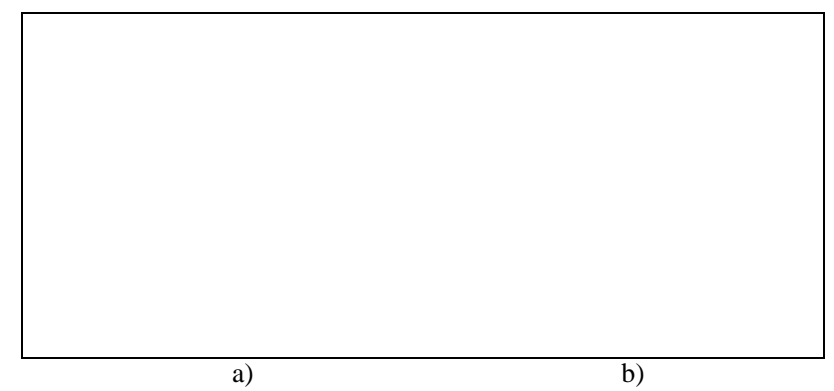

Fig. 4. a) Semi-finished piece, b)Working post blocking system

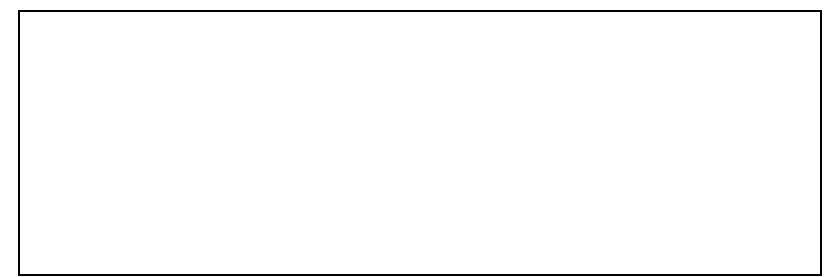

Fig. 5. a-Storage stations, b-Electromechanical limiters

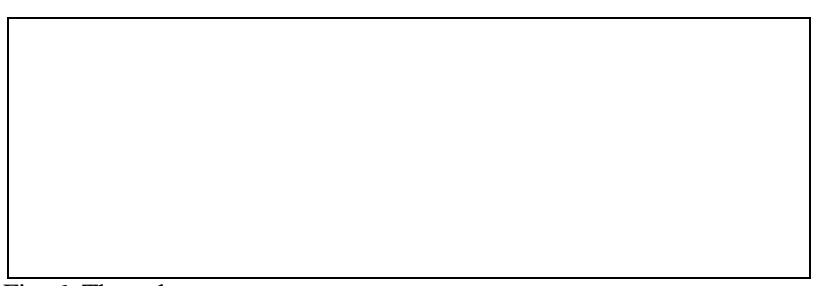

Fig. 6. The palette
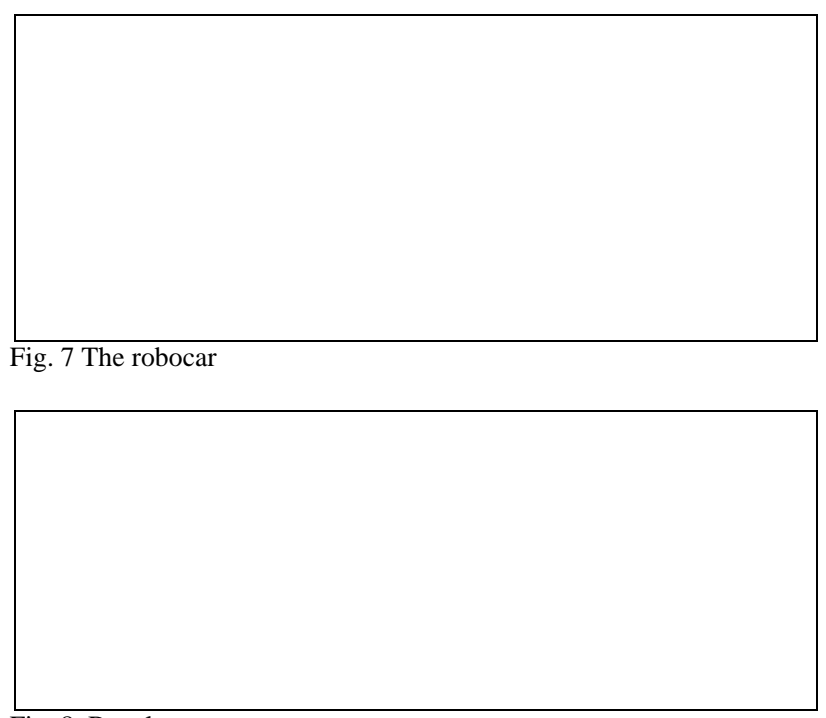

Fig. 8. Bevel gears

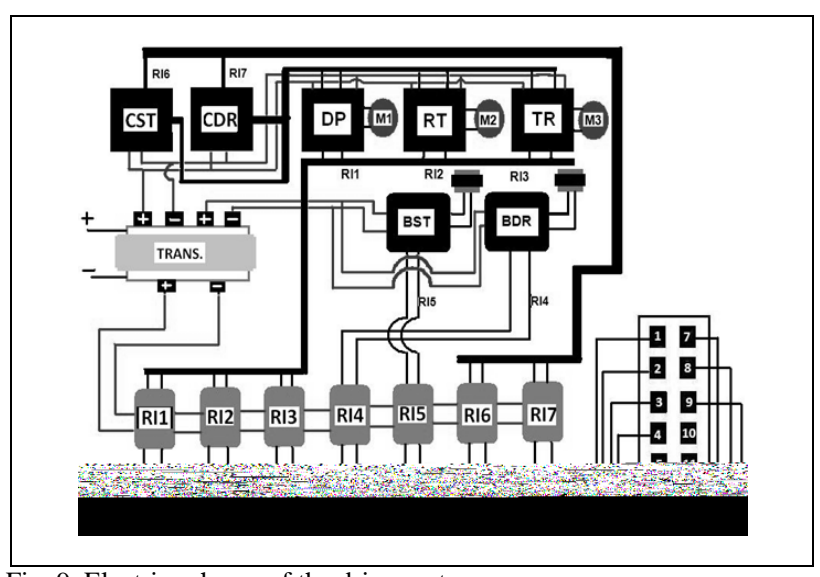

Fig. 9. Electric schema of the drive system

\subsection{Controlsystemactuatingpower, transport, transfer FMS350}

Power system control, is made from a PLC [4], power electronics is represented by relays of both actuators and linkages to help block range electromagnets on the transfer system and in the workstation. The electric scheme of drive system is shown in Figure 5.

DP-movetrolley;

RT-rotationof the palletsretrieval system;

TR-translationretrieval systempaletts;

CST-moveto left;

CDR-move to right;

BST-setleftelectromagnet;

BDR- setrightelectromagnet;

1- Setthe coilright;

2 -Transfer-taking range;

3 -Rotatingbladesystemtakeover;

4 -Movetrolley;

5-Ground;

7- Turnleftcoil;

8 -Contactactivationmovetoright;

9 -Contactactivationmovetoleft.

\section{DATA ACQUISITIONIN THE WORKING ENVIRONMENT}

Identification of partsthat are tobeprocessedisusingradio frequencyidentification [6]. Thuseachpallet isplaced atagthat allowsidentification. 

files. Ifno data iswritten to thefilethen itwillcreatea new file.

Following the acquisition ofdatafileswere madeinthe figure 13putthe folder structurespecifiedin thegeneralstructure ofthisfile.The contents of a file is shown in figure 14.

ThususingTablesGeneratorcreateda databaseinSQLServerwiththe configuration shown in figure 15.

Inthis structurewillenterdata fromeach stationto paymeasurementdatato an event. The softwareallowsconnectionof5 sensors, so thecolumnsof this table will be provided the following data:

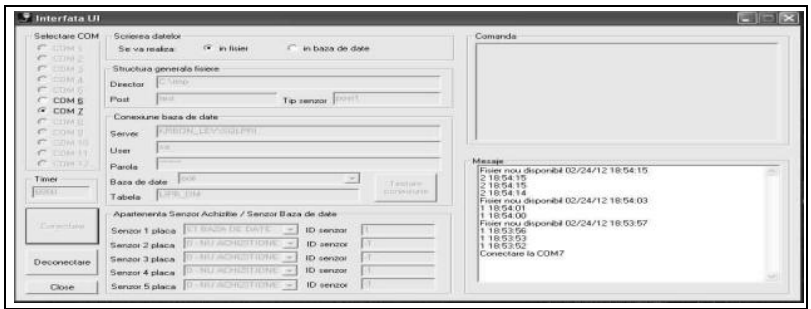

Fig. 12. Acquired data in software application

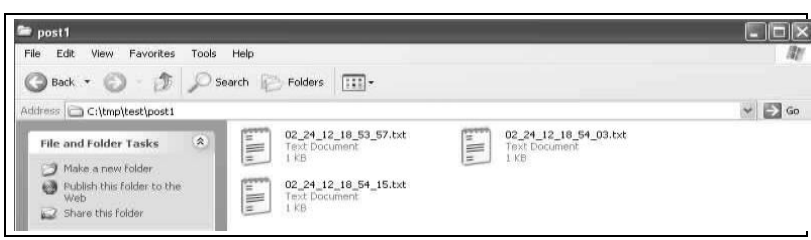

Fig. 13. Files created by application

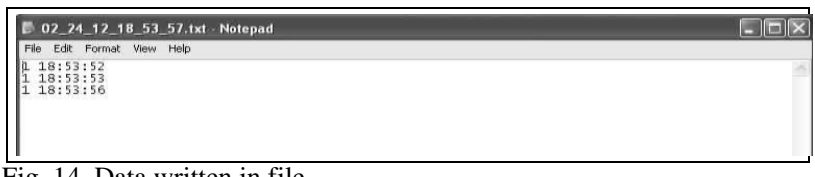

Fig. 14. Data written in file

a) IDdm-IDregistration;

b) IDpost-JobIDfrom whichto retrievedata;

c) IDs1-IDs5-IDthefivesensorsonthispost;

d) VALs1-VALs5

-takenfroma measurementvaluefromthese sensors;

e) DATAdm-date ofeventmeasurementwas taken;

f) ERRdm-an error codeifan error occursinthe data input.

Datatobeenteredin the databasewillbeset upwork areaconnectionto the database.Data acquired bythe application arethus introducedintothe appropriatedatabasetableLIP_DM.

\begin{tabular}{|c|c|c|c|c|c|}
\hline \multirow{2}{*}{\multicolumn{6}{|c|}{$\begin{array}{l}\text { Table - dbo.LPP_DM } M^{*} \text { CSummary } \\
\text { Column Name }\end{array}$}} \\
\hline & & & & & Allow Nults \\
\hline 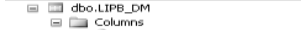 & $\hat{\imath}$ & & $\begin{array}{l}\text { IDdm } \\
\text { IDPost }\end{array}$ & $\begin{array}{l}\text { int } \\
\text { int }\end{array}$ & 믐 \\
\hline $\begin{array}{l}\text { IDdm (PK, int, not null) } \\
\text { If }\end{array}$ & & & IDcomando & varchar(50) & ㅁ \\
\hline $\begin{array}{l}\text { 腮 IDcomanda (varchar(50), null) } \\
\text { IDS1 (int, null) }\end{array}$ & & $=$ & IDs1 & & 回 \\
\hline IDs2 (int, null) & & & IDs2 & int & 回 \\
\hline $\begin{array}{l}\text { IDs3 (int, null) } \\
\text { Ins4 (nit) }\end{array}$ & & & IDs3 & int & 回 \\
\hline 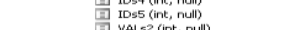 & & & $\begin{array}{l}\text { IDS4 } \\
\text { IDs5 }\end{array}$ & $\begin{array}{c}\text { int } \\
\text { int } \\
\text { int }\end{array}$ & 㘣 \\
\hline 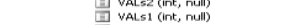 & & & VALS2 & int & \\
\hline 狊 VALs (int, null) & & & VALS1 & int & 司 \\
\hline 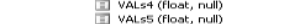 & & & VALS3 & int & \\
\hline DATAdm (int, nuli) & & & VAls4 & Float & 回 \\
\hline Thrdm (lint, null) & & & $\begin{array}{l}\text { VALS5 } \\
\text { DATAdm }\end{array}$ & $\begin{array}{l}\text { Float } \\
\text { int }\end{array}$ & 品 \\
\hline 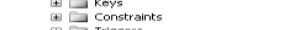 & & & ERRdm & Int & 吕 \\
\hline
\end{tabular}

Fig. 15. Tables created in Priority environment

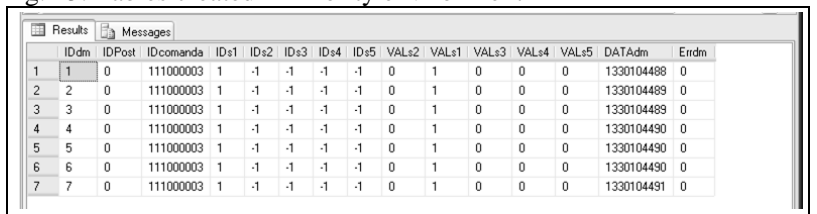

Fig. 16. Writing data in software application g) IDdm-IDregistration;

h) IDpost-JobIDfrom whichto retrievedata;

i) IDs1-IDs5-IDthefivesensorsonthispost;

j) VALs1-VALs5

measurementvaluefromthese sensors;

k) DATAdm-date ofeventmeasurementwas taken;

1) ERRdm-an error codeifan error occursinthe data input.

Datatobeenteredin the databasewillbeset upwork areaconnectionto the database.Data acquired bythe application arethus introducedintothe appropriatedatabasetableLIP_DM.

\section{CONCLUSION}

The control panel of the supply, transport, transfer systems has been upgraded to operate in automatic mode.

RFID tags have been mounted on palettes so any palette can be identified.

Using the RFID readers have been taken information regarding the highlights positioned on the palettes. These information refer to weight, shape and the number of operations made on one object. After acquisition, the data is automatically processed in specially designed tables in Priority, the enterprie resource planning software. Therefore these table will contain information about each highlights.

Further more, the data base transfer of the ERP would need the restructuring of the data and raports flow.

In furure, the data acquisition will be made using more complex structures which will include processing centers, supply, transport and storage systems.

\section{ACKNOWLEDGEMENTS}

The work has been funded by the Sectoral Operational Programme Human Resources Development 2007-2013 of the Romanian Ministry of Labour, Family and Social Protection through the Financial Agreement POSDRU/107/1.5/S/76903.

\section{REFERENCES}

[1] W. Bolton, (2004) Instrumentation and Control Systems, Newnes, USA

[2] Felix BÖSE, Katja WINDT, Michael TEUCKE (2006). Modelling of autonomously controlled logistic processes in production systems, Proceedings of 8th MITIP Conference, MITIP2006, 11-12 September, Budapest

[3] Groover, M. P. (2007). Automation, Production Systems, and Computer Integrated Manufacturing, Prentice Hall, New Jersey

[4] W. Bolton, (2009). Programmable Logic Controllers, Elsevier, USA

[5] Adrian POPESCU, George ENCIU (2011). Data acquisition regarding the landmarks achieved inside a manufacturing flexible cell, Proceedings in Manufacturing Systems, Volume 6, Issue 3, ISSN 2067-9238, Bucharest

[6]George Enciu (2011). Logistica Intreprinderilor Industriale, Fair Partners, ISBN 978-973-1877-53-2, Bucuresti

[7]http://www.robofun.ro/arduino/arduino_uno_v3, (2012). Data acquisition board, Accessed on: 2012-02-11

[8] http://www.wizrom.ro, (2012). ERP, Wizpro, Accessed on: 2012$03-20$

[9] http://www.robofun.ro/senzori/id, (2012). RFID reades, Accessed on: 2012-03-23 